\title{
PENGARUH DER DAN INVESTMENT OPPORTUNITY SET TERHADAP NILAI PERUSAHAAN
}

\author{
Wachidah Fauziyanti, Enny Puji Astuti \\ Prodi Manajemen STIE SEMARANG
}

\begin{abstract}
This research was performed to analyze the influence of debt equity ratio (DER) and investment opportunity set (IOS) on firm value. Sample of this research was companies listed in Indonesian Stock Exchange (BEI) and include in the LQ 45 index for the period of 2004-2006. Data was collected from annual reports recorded in the 2007 Indonesian Capital Market Directory (ICMD) and was analyzed using regression model. The result of this research showed that DER negatively and IOS positively affected firm values.
\end{abstract}

Key words : debt equity ratio, investment opportunity set and firm value

\begin{abstract}
ABSTRAK
Penelitian ini menganalisa pengaruh dari hutang (DER) dan investasi atau investment opportunity set (IOS) terhadap nilai perusahaan. Sampel penelitian dari perusahaan yang terdaftar di Bursa Efek Indonesia yang termasuk indeks LQ45 periode 2004-2006. Pengumpulan data dari laporan keuangan yang terdapat dalam Indonesian capital Market Directory (ICMD) tahun 2007. Penelitian ini menggunakan analisa regresi. Hasil penelitian menunjukkan hutang berpengaruh negatif terhadap nilai perusahaan dan investasi (IOS) berpengaruh positif terhadap nilai perusahaan.
\end{abstract}

Kata kunci : debt equity ratio, investment opportunity set dan nilai perusahaan.

\section{Pendahuluan}

Tujuan utama perusahaan adalah memaksimalkan nilai perusahaan, bagi perusahaan yang menerbitkan saham di pasar modal harga saham yang ditransaksikan di bursa merupakan indikator nilai perusahaan. Seiring dengan perkembangan pasar modal di Indonesia dan semakin tinggi transaksi dan volume perdagangan saham, kebutuhan atas informasi yang relevan dalam pengambilan keputusan investasi semakin meningkat. Salah satu informasi yang banyak digunakan adalah informasi akuntansi yang berasal dari laporan keuangan. 
Perusahaan yang menentukan kebijakan hutang dalam struktur modal sepanjang perusahaan mampu menyeimbangkan manfaat dan biaya yang ditimbulkan akibat hutang tidak menjadi masalah. Di sisi lain kepercayaan investor terhadap keputusan meningkatkan hutang perusahaan menunjukkan kemampuan perusahaan menanggung resiko yang dihadapi, bahkan ada kecenderungan keputusan tersebut untuk meningkatkan nilai perusahaan.

Kesempatan investasi perusahaan merupakan komponen penting dari nilai pasar, karena investment opportunity set (IOS) dari suatu perusahaan mempengaruhi cara pandang manajer, pemilik, investor dan kreditor terhadap perusahaan, karena proksi IOS perusahaan harus menjadi pemikiran sebagai prospek pertumbuhan bagi perusahaan. Menurut Husnan (2004) nilai perusahaan merupakan harga yang bersedia dibayar oleh calon pembeli apabila perusahaan tersebut dijual. Wahyudi dan Pawestri (2006) menyatakan bahwa nilai perusahaan yang dibentuk melalui indikator nilai pasar saham, sangat dipengaruhi oleh peluang-peluang investasi. Pengeluaran investasi memberikan sinyal positif tentang pertumbuhan perusahaan di masa yang akan datang, sehingga meningkatkan harga saham sebagai indikator nilai perusahaan (signaling theory). Konsep yang paling repsentatif untuk menentukan nilai suatu perusahaan adalah konsep intrinsik. Nilai perusahaan dalam konsep nilai intrinsik ini bukan sekedar harga dari sekumpulan nilai aset, melainkan nilai perusahaan sebagai intensitas bisnis yang memiliki kemampuan menghasilkan keuntungan dikemudian hari.

Penelitian mengenai Santika (2002) mengenai pengaruh penggunaan hutang terhadap dalam struktur modal perusahaan industri berpengaruh positif dalam meningkatkan nilai perusahaan. Soliha et al (2002) dalam penelitian mengenai kebijakan hutang terhadap nilai perusahaan menunjukkan adanya pengaruh positif namun tidak signifikan terhadap nilai perusahaan. hasil penelitian berbeda diperoleh Setyaningsih (2000) dan Sugiarto (20070 yang membuktikan bahwa kebijakan hutang berpengaruh negatif signifikan terhadap harga saham.

Hasil penelitian pengaruh IOS (Investment Opportunity Set) terhadap nilai perusahaan menunjukkan perbedaan. Penelitian Rachmawati dan Triatmoko (2007) menunjukkan hasil adanya pengaruh positif IOS terhadap nilai perusahaan. 
Pengeluaran investasi memberikan sinyal yang positif tentang pertumbuhan perusahaan di masa yang akan datang. Hasil penelitian berbeda dibuktikan oleh Suranta dan Machfoedz (2002) bahwa variabel investasi berpengaruh negatif signifikan terhadap nilai perusahaan.

\section{Masalah Penelitian}

Berdasarkan hasil penelitian terdahulu menunjukkan adanya feaomena empiris dan research gap pada variabel hutang (DER) dan Investasi (IOS) yang mempengaruhi nilai perusahaan. Rumusan masalah dalam penelitian ini adalah “ apakah hutang (debt equity ratio) dan investasi (investment opportunity set) berpengaruh terhadap nilai perusahaan".

\section{Kajian Teoritis}

Nilai Perusahaan

Nilai perusahaan adalah persepsi investor terhadap tingkat keberhasilan perusahaan yang sering dikaitkan dengan harga saham. Harga saham yang tinggi membuat nilai perusahaan juga tinggi, dan meningkatkan kepercayaan pasar tidak hanya terhadap kinerja perusahaan saat ini namun juga pada prospek perusahaan di masa mendatang. Memaksimalkan nilai perusahaan sangat penting artinya bagi suatu perusahaan, karena dengan memaksimalkan nilai perusahaan berarti juga memaksimalkan tujuan utama perusahaan. Meningkatnya nilai perusahaan adalah sebuah prestasi yang sesuai dengan keinginan para pemiliknya, karena dengan meningkatnya nilai perusahaan, maka kesejahteraan para pemilik juga akan meningkat.

Menurut Noerirawan (2012), nilai Perusahaan merupakan kondisi yang telah dicapai oleh suatu perusahaan sebagai gambaran dari kepercayaan masyarakat terhadap perusahaan setelah melalui suatu proses kegiatan selama beberapa tahun, yaitu sejak perusahaan tersebut didirikan sampai dengan saat ini. Nilai perusahaan dapat diukur dengan menggunakan harga saham menggunakan rasio yang disebut rasio penilaian. Menurut Sudana (2011:23), rasio Penilaian adalah suatu rasio yang terkait dengan penilaian kinerja saham perusahaan yang 
telah diperdagangkan di pasar modal (go public). Rasio penilaian memberikan informasi seberapa besar masyarakat menghargai perusahaan, sehingga masyarakat tertarik untuk membeli saham dengan harga yang lebih tinggi dibanding nilai bukunya.

Metode yang digunakan untuk mengukur nilai perusahaan adalah Price to Book Value (PBV) adalah rasio yang menunjukkan apakah harga saham yang diperdagangkan overvalued (di atas) atau undervalued (di bawah) nilai buku saham tersebut (Fakhruddin dan Hadianto, 2001). Price to Book Value (PBV) menggambarkan seberapa besar pasar menghargai nilai buku saham suatu perusahaan. Makin tinggi rasio ini, berarti pasar percaya akan prospek perusahaan tersebut. PBV juga menunjukkan seberapa jauh suatu perusahaan mampu menciptakan nilai perusahaan yang relatif terhadap jumlah modal yang diinvestasikan Untuk perusahaan-perusahaan yang berjalan dengan baik, umumnya rasio ini mencapai diatas satu, yang menunjukkan bahwa nilai pasar saham lebih besar dari nilai bukunya. Semakin besar rasio PBV semakin tinggi perusahaan dinilai oleh para pemodal relatif dibandingkan dengan dana yang telah ditanamkan di perusahaan. Adapun rumus yang digunakan untuk mengukur Price to Book Value (PBV) adalah sebagai berikut:

Price to book Value $(\mathrm{PBV})=\frac{\text { Harga pasar per lembar saham }}{\text { Nilai buku per lembar saham }}$

Hutang (debt equity ratio)

Copeland et al, 1994 (dalam sinergi, 1999) menyatakan bahwa memaksimumkan nilai perusahaan (company value) saat ini disepakati sebagai tujuan dari setiap perusahaan, terutama yang berorientasi laba. Nilai pemegang saham akan meningkat apabila nilai perusahaan meningkat yang ditandai dengan tingkat pengembalian investasi yang tinggi kepada pemegang saham. Nilai perusahaan diyakini tidak hanya mencerminkan kinerja perusahaan saat ini tetapi juga menggambarkan prospek perusahaan di masa yang akan datang. Fama (1978) dalam Wahyudi (2006) menyatakan dalam jangka panjang, tujuan perusahaan adalah mengoptimalkan nilai perusahaan, semakin tinggi nilai perusahaan 
menggambarkan semakin sejahtera pula pemiliknya. Bagi perusahaan yang menerbitkan saham di pasar modal harga saham yang ditransaksikan di bursa merupakan indikator nilai perusahaan.

Balancing theory menyatakan bahwa sepanjang perusahaan mampu menyeimbangkan manfaat dan biaya yang ditimbulkan akibat hutang, kebijakan hutang tidak menjadi masalah. Struktur modal dengan kebijakan hutang juga berperan memperkecil inefisiensi dalam keputusan investasi perusahaan. Karena perusahaan-perusahaan pada dasarnya berupaya menyeimbangkan biaya-biaya (costs) dan manfaat manfaat (benefits) hutang sampai pada suatu leverage ratio yang optimal. Tetapi di sisi lain dampak yang ditimbulkan dari kebijakan hutang adalah munculnya resiko bila ditinjau dari sisi solvabilitas, bila rasio yang tinggi relatif kurang baik, karena bila terjadi likuidasi perusahaan akan mengalami kesukaran (Alwi, 1983).

Debt equity ratio (DER) atau rasio hutang merupakan perbandingan antara jumlah total hutang terhadap total equity ( Alwi,1983) atau perbandingan antara total hutang dengan total aktiva. DER menunjukkan seberapa besar asset perusahaan diperoleh atau didanai dengan hutang. DER juga menunjukkan resiko yang dihadapi oleh perusahaan berkaitan dengan hutang yang dimiliknya. Rasio DER perusahaan yang tinggi menunjukkan bahwa perusahaan memiliki ketergantungan yang tinggi untuk kegiatan operasional perusahaan terhadap modal usaha yang berasal dari hutang pada pihak eksternal.

$$
\text { Debt to Equity Ratio (DER) }=\frac{\text { Total Hutang }}{\text { Total ekuitas }}
$$

- Hutang atau Kewajiban (Liabilities) adalah kewajiban yang harus dibayarkan secara tunai ke pihak lain dalam jangka waktu tertentu. Berdasarkan jangka waktu pelunasannya, Kewajiban atau hutang ini biasanya diklasifikasikan menjadi Kewajiban lancar, kewajiban jangka panjang dan kewajiban lainlain.

- $\quad$ Ekuitas (Equity) adalah hak pemilik atas aset atau aktiva perusahaan yang merupakan kekayaan bersih (jumlah aktiva dikurangi dengan kewajiban). 
Ekuitas dapat terdiri dari setoran pemilik perusahaan dan sisa laba yang ditahan (retained earning).

\section{Investment Opportunity set (IOS)}

Myers (1977) memperkenalkan set peluang investasi (investment opportunity set) untuk pertama kalinya dalam kaitannya untuk mencapai tujuan perusahaan. Myers (1977) menguraikan tentang pengertian perusahaan yang terdiri dari suatu kombinasi antara aset yang dimiliki oleh perusahaan dengan pilihan investasi masa depan perusahaan. Menurut Myers (1977) Investment opportunity set memberikan petunjuk yang lebih luas dimana nilai perusahaan sebagai tujuan utama tergantung pada pengeluaran perusahaan di masa yang akan datang. Investment Opportunity Set adalah tersedianya alternatif investasi di masa datang bagi perusahaan (Hartono, 1999). IOS merupakan suatu keputusan investasi yang merupakan bentuk kombinasi antara aktiva yang dimiliki (assets in place) dan pilihan investasi dimasa yang akan datang. Menurut Gaver dan Gaver (1993), IOS merupakan nilai perusahaan yang besarnya tergantung pada pengeluaran-pengeluaran yang ditetapkan manajemen di masa yang akan datang, yang pada saat ini merupakan pilihan-pilihan investasi yang diharapkan akan menghasilkan return yang lebih besar.

Investment Opportunity Set (IOS) merupakan proksi kombinasi dari pertumbuhan perusahaan (Smith dan Watts, 1986). Nilai IOS dihitung dengan kombinasi dari berbagi jenis proksi yang menggambarkan nilai aktiva ditempat dan nilai kesempatan tumbuh perusahaan dimasa depan (yang digambarkan berupa nilai pasar). IOS merupakan kombinasi dari nilai aktiva ditempat dan nilai kesempatan dimasa depan. Kallapur dan Trombley, (1999) menyatakan bahwa kesempatan investasi perusahan tidak dapat diobservasi untuk pihak-pihak di luar perusahaan. Gaver dan Gaver (1993) menyatakan Investment Opportunity Set perusahaan merupakan sesuatu yang secara melekat tidak dapat diobservasi, dikarenakan Investment Opportunity Set merupakan variabel yang tidak dapat diobservasi, oleh karena itu diperlukan proksi (Hartono, 1999) dalam Norpratiwi (2004). 
Pada penelitian ini IOS menggunakan proksi berbasis harga yang mendasarkan pada perbedaan antara asset dan nilai perusahaan dan rasio yang digunakan market value of assets to book value of assets ( MVBVA). Simbol yang digunakan IOS, secara matematis rumus yang digunakan adalah

$$
\text { MVBVA }=\frac{(\text { total asset-total ekuitas })+(\text { jml saham beredar } x \text { close price })}{\text { Total asset }}
$$

Kerangka pemikiran teoritis penelitian :

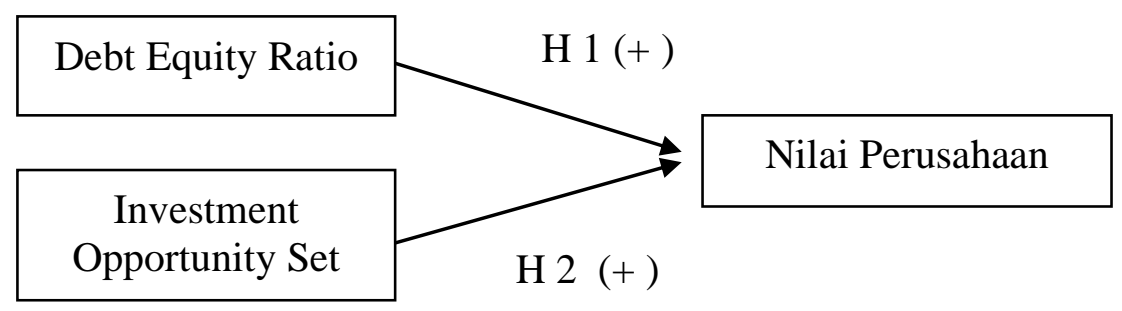

Perumusan hipotesis penelitian :

H 1 : DER berpengaruh positif dan signifikan terhadap nilai perusahaan

H 2 : IOS berpengaruh positif signifikan terhadap nilai perusahaan

\section{Metodologi}

Penelitian ini menggunakan data sekunder yang bersumber dari data laporan keuangan perusahaan go publik yang termasuk indeks LQ45 periode per semester dari tahun 2004 sampai dengan 2006 di Bursa Efek Indonesia yang termuat dalam Indonesian Capital market Directory dan Jakarta Stock Exchange (JSX) dan laporan Bursa Efek Indonesia. Metode pengumpulan data dengan cara teknik pooling data (time series cross sectional). Pooling data dilakukan dengan cara menjumlahkan perusahaan-perusahaan yang memenuhi kriteria selama periode pengamatan. 
Sampel final yang diperoleh ada 11 perusahaan dikalikan 6 semester periode pengamatan atau 3 tahun. Adapun sampel emiten final yang diperoleh adalah:

1. Astra Agro Lestari Tbk,

2. Aneka Tambang (Persero) Tbk

3. Astra International Tbk

4. Gudang garam Tbk

5. Gajah tunggal Tbk

6. Indofood sukses makmur Tbk

7. Indosat tbk

8. Kalbe farma Tbk

9. Telekomunikasi Indonesia Tbk

10. United Tractors Tbk

11. Unilever Indonesia Tbk

Metodologi penelitian dengan metode analisis

a. Analisis Regresi

Metode analisis regresi pada dasarnya adalah studi mengenai ketergantungan variabel dependen dengan satu atau lebih variabel independen dengan tujuan untuk mengestimasi dan/atau memprediksi rata-rata populasi atau nilai ratarata variabel dependen berdasarkan nilai variabel independen yang diketahui (Gujarati,2003 dalam Imam Ghozali, 2006). Pengujian dengan model regresi linier berganda dengan persamaan sebagai berikut :

$$
\mathrm{PBV}=\beta \mathrm{O}+\beta 1 \mathrm{DER}+\beta 2 \mathrm{IOS}+\mathrm{e}
$$

$$
\begin{aligned}
& \text { PBV : Nilai Perusahaan } \\
& \text { Bo : Konstanta } \\
& \beta 1 D E R \text { : debt equity ratio } \\
& \beta 2 \mathrm{IOS} \text { : Investment Opportunity set } \\
& \mathrm{e} \quad \text { : residual }
\end{aligned}
$$


Hasil analisis regresi

Koefisien Determinasi

\begin{tabular}{ll|r|r|r} 
& & \multicolumn{2}{c}{ Model Summary } \\
Model & R & R Square & \multicolumn{1}{c}{$\begin{array}{c}\text { Adjusted R } \\
\text { Square }\end{array}$} & $\begin{array}{l}\text { Std. Error of } \\
\text { the Estimate }\end{array}$ \\
\hline 1 &, $992^{\mathrm{a}}$ &, 985 &, 981 &, 51773 \\
\hline
\end{tabular}

a. Predictors: (Constant), IOS, DER

Dari hasil analisis output SPSS model summary besarnya adjusted $\mathrm{R}^{2}$ adalah 0,981, hal ini berarti 98,1\% variasi PBV dapat dijelaskan oleh variasi IOS dan DER. Sedangkan sisanya $(100 \%-98,1 \%=1,9 \%)$ dijelaskan oleh sebab-sebab yang lain di luar model.

\begin{tabular}{|c|c|c|c|c|c|c|}
\hline \multicolumn{7}{|c|}{ ANOVA $^{\mathrm{a}}$} \\
\hline \multicolumn{2}{|c|}{ Model } & $\begin{array}{l}\text { Sum of } \\
\text { Squares }\end{array}$ & Df & Mean Square & $\mathrm{F}$ & Sig. \\
\hline \multirow[t]{3}{*}{1} & Regression & 140,668 & 2 & 70,334 & 262,399 &, $000^{\mathrm{b}}$ \\
\hline & Residual & 2,144 & 8 & ,268 & & \\
\hline & Total & 142,812 & 10 & & & \\
\hline
\end{tabular}

a. Dependent Variable: PBV

b. Predictors: (Constant), IOS, DER

Dari uji ANOVA atau F test didapat nilai F hitung sebesar 262,399 dengan probabilitas 0,000. Karena probabilitas jauh lebih kecil dari 0,05 maka model regresi dapat digunakan untuk memprediksi PBV atau DER dan IOS secara bersama-sama berpengaruh terhadap PBV.

\begin{tabular}{|c|c|c|c|c|c|c|}
\hline \multicolumn{7}{|c|}{ Coefficients $^{\mathrm{a}}$} \\
\hline \multirow{2}{*}{\multicolumn{2}{|c|}{ Model }} & \multicolumn{2}{|c|}{$\begin{array}{l}\text { Unstandardized } \\
\text { Coefficients }\end{array}$} & \multirow{2}{*}{$\begin{array}{c}\text { Standardized } \\
\text { Coefficients } \\
\text { Beta } \\
\end{array}$} & \multirow[b]{2}{*}{$\mathrm{t}$} & \multirow[b]{2}{*}{ Sig. } \\
\hline & & $\mathrm{B}$ & Std. Error & & & \\
\hline \multirow[t]{3}{*}{1} & (Constant) &,- 393 & ,260 & & $-1,513$ & , 169 \\
\hline & DER &,- 034 & ,088 &,- 020 &,- 386 & ,710 \\
\hline & IOS & 1,733 &, 089 & 1,003 & 19,506 &, 000 \\
\hline
\end{tabular}

a. Dependent Variable: PBV 
Unstandardized beta Coefficients : dari kedua variabel independen yang dimasukkan ke dalam model regresi variabel DER tidak signifikan hal ini dapat dilihat dari probabilitas signifikansi sebesar 0,710 jauh di atas 0,05. Sedangkan variabel IOS signifikan pada 0,05. Dapat disimpulkan bahwa variabel PBV dipengaruhi oleh DER dan IOS dengan persamaan matematis :

$$
\mathrm{PBV}=0,393-0,034 \mathrm{DER}+1,733 \text { IOS }
$$

b. Uji Penyimpangan Asumsi Klasik

Karena data yang digunakan adalah data sekunder untuk menentukan ketepatan model maka digunakan uji penyimpangan klasik yang terdiri dari

- Uji Normalitas yang bertujuan untuk menguji apakah dalam model regresi, variabel dependen dan independen keduanya mempunyai distribusi normal atau mendekati normal (Gozhali, 2005)

Hasil output SPSS uji Normalitas

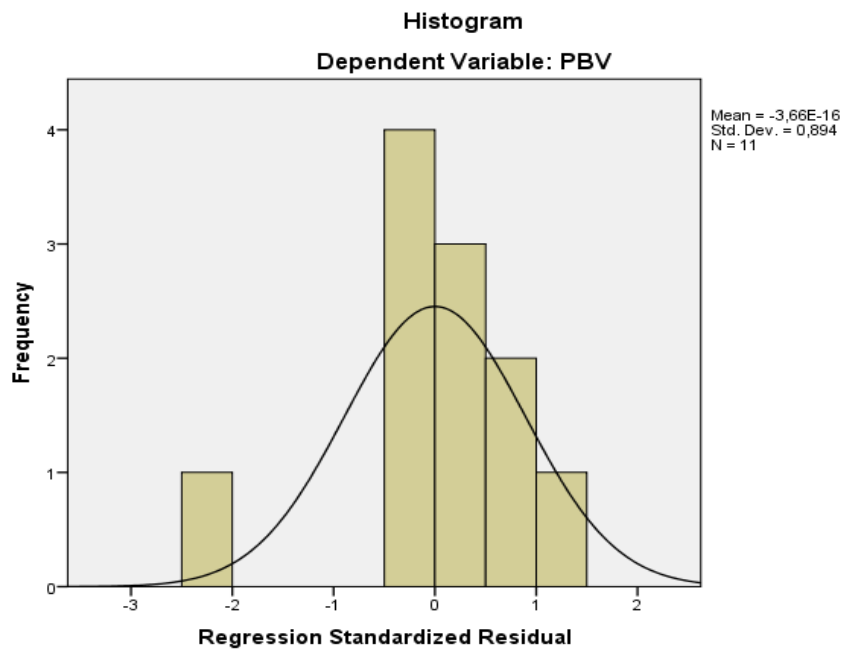

Membentuk kurve normal dan sebagian besar bar/batang berada di bawah kurve, maka variabel berdistribusi normal. 


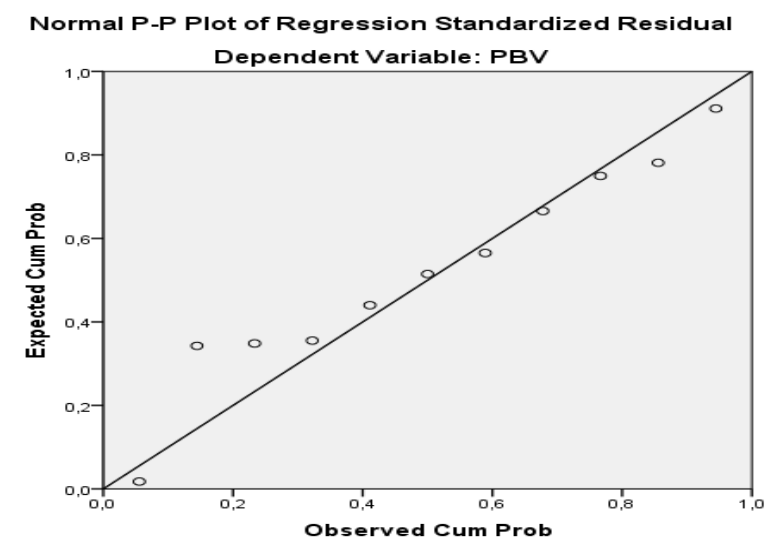

Dari grafik normal plot dapat disimpulkan data menyebar di sekitar garis diagonal dan mengikuti arah garis diagonal atau grafik histogramnya menunjukkan pola distribusi normal maka model regresi memenuhi asumsi normalitas.

- Uji Multikolinieritas bertujuan untuk menguji apakah model regresi ditemukan adanya korelasi antar variabel independen.

\begin{tabular}{lllr|r}
\multicolumn{5}{c}{ Coefficient Correlations $^{\mathrm{a}}$} \\
Model & & \multicolumn{1}{c}{ IOS } & \multicolumn{1}{c}{ DER } \\
\hline \multirow{2}{*}{\begin{tabular}{l} 
Correlations \\
\cline { 3 - 5 }
\end{tabular}} & IOS & 1,000 &,- 539 \\
\cline { 2 - 5 } & DER &,- 539 & 1,000 \\
\cline { 3 - 5 } & Covariances & IOS &, 008 &,- 004 \\
\cline { 3 - 5 } & & DER &,- 004 &, 008 \\
\hline
\end{tabular}

a. Dependent Variable: PBV

\begin{tabular}{llr|r|r|r|r}
\multicolumn{2}{l}{$\begin{array}{l}\text { Mod } \\
\text { el }\end{array}$} & Dimension & Eigenvalue & Index & \multicolumn{3}{c}{ Variance Proportions } \\
(Constant) & DER & IOS \\
\hline 1 & 1 & 2,549 & 1,000 &, 05 &, 04 &, 04 \\
\cline { 2 - 8 } & 2 &, 256 & 3,154 &, 95 &, 25 &, 14 \\
\hline & 3 &, 195 & 3,613 &, 01 &, 71 &, 82 \\
\hline
\end{tabular}

Dari hasil besaran korelasi antara variabel independen tampak bahwa variabel DER yang mempunyai korelasi sebesar -0,539 dengan variabel IOS atau sekitar $54 \%$, karena korelasi masih dibawah $95 \%$ maka dapat dikatakan tidak terjadi multikolonieritas yang serius. 
- Uji Heteroskesdastisitas bertujuan untuk menguji apakah dalam model regresi terdapat ketidaksamaan variance dari residual satu pengamatan ke pengamatan lainnya (Ghozali,2005).

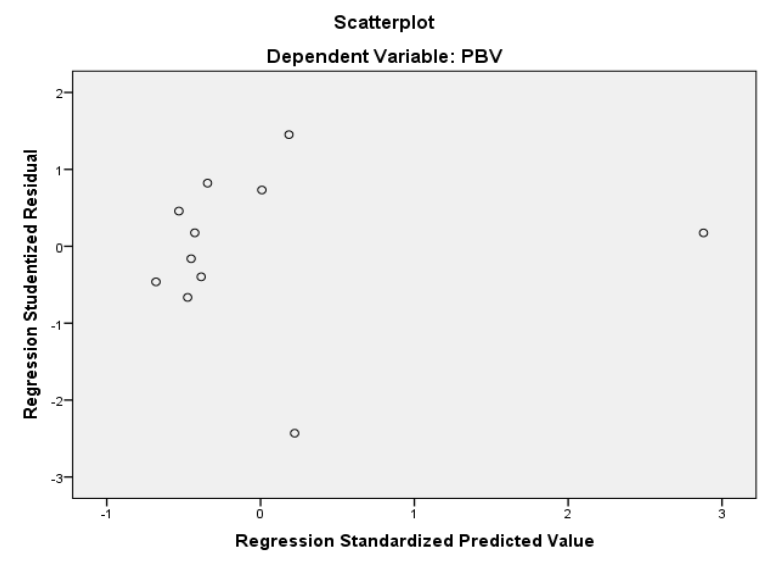

Dari hasil uji heteroskedastisitas grafik diatas terlihat bahwa titik-titik menyebar di atas dan di bawah angka 0 pada sumbu Y maka disimpulkan tidak terjadi heteroskedastisitas.

- Uji Autokorelasi bertujuan untuk menguji apakah dalam suatu model regresi linier terjadi korelasi antara kesalahan pengganggu pada selama periode pengamatan yang tersusun dalam rangkaian waktu seperti pada time series atau ruang seperti pada data cross section (Gujarati,1995)

Uji autokorelasi pada penelitian ini menggunakan uji Durbin Watson hanya digunakan untuk autokorelasi tingkat satu dan mensyaratkan adanya intercept (konstanta) dalam model regresi dan tidak ada variabel lag di antara variabel independen. Hasil uji Durbin watson : 


\begin{tabular}{ll|r|r|r|r} 
& \multicolumn{9}{c}{$\begin{array}{c}\text { Model Summary } \\
\text { Model }\end{array}$} & R & R Square & $\begin{array}{c}\text { Adjusted R } \\
\text { Square }\end{array}$ & $\begin{array}{c}\text { Std. Error of } \\
\text { the Estimate }\end{array}$ & $\begin{array}{c}\text { Durbin- } \\
\text { Watson }\end{array}$ \\
\hline 1 &, $992^{\mathrm{a}}$ &, 985 &, 981 &, 51773 &, 830 \\
\hline
\end{tabular}

a. Predictors: (Constant), IOS, DER

b. Dependent Variable: PBV

Sampel 11.

variabel 3.

DL 0,75798

Du 1,60439

Dw 0,830

Perhitungan durbin watson nilai DL $<$ DW $>$ DU dan DL $<(4-D W)>$ DU maka tidak terjadi autokorelasi. Sehingga perhitungan dari hasil uji durbin watson adalah $0,75798<(4-0,830)>1,60439$ atau $0,75798<3,17>$ 1,60439 Berdasarkan perhitungan tersebut, maka dapat dikatakan tidak ada autokorelasi.

\section{Pembahasan}

Hasill analisis menyatakan bahwa hipotesis dari kerangka pemikiran teoritis dan hasil penelitian tidak terdapat konsistensi dimana nilai koefisien regresi DER sebesar 0,034 menunjukkan tanda negatif. Hasil ini mendukung penelitian yang diperoleh Setyaningsih (2000) dan Sugiarto (2007) yang membuktikan bahwa kebijakan hutang berpengaruh negatif signifikan terhadap harga saham. Hasil ini menyatakan bahwa perusahaan yang mengambil kebijakan hutang dikhawatirkan akan memiliki ketergantungan yang tinggi terhadap modal usaha yang berasal dari hutang pada pihak eksternal. Dengan demikian sebagian besar modal yang digunakan dalam kegiatan operasional perusahaan dengan cara berhutang akan rentan dengan meningkatkan biaya kebangkrutan. Pernyataan ini menurut Barclay dan Smith (1998, dalam Subekti dan Kusuma 2001) konsisten dengan prediksi teori contracting yang mengisyaratkan bahwa perusahaan yang memiliki opsi untuk tumbuh lebih besar akan memiliki hutang yang lebih sedikit dikarenakan perusahaan lebih mengutamakan solusi atas masalah-masalah yang berkaitan dengan hutangnya. 
Sesuai dengan pecking order theory (Myers ,2001) menyatakan bahwa "Perusahaan dengan tingkat profitabilitas yang tinggi justru tingkat utangnya rendah, dikarenakan perusahaan yang profitabilitasnya tinggi memiliki sumber dana internal yang berlimpah." Dalam pecking order theory ini tidak terdapat struktur modal yang optimal. Secara spesifik perusahaan mempunyai urut-urutan preferensi (hierarki) dalam penggunaan dana.

Pecking order theory menjelaskan mengapa perusahaan mempunyai uruturutan preferensi dalam memilih sumber pendanaan. Perusahaan-perusahaan yang profitable umumnya meminjam dalam jumlah yang sedikit. Hal tersebut disebabkan karena mereka memerlukan external financing yang sedikit. Perusahaan-perusahaan yang kurang profitable cenderung mempunyai hutang yang lebih besar karena alasan dana internal yang tidak mencukupi kebutuhan dan karena hutang merupakan sumber eksternal yang disukai. Dana eksternal lebih disukai dalam bentuk hutang daripada modal sendiri karena pertimbangan biaya emisi hutang jangka panjang yang lebih murah dibanding dengan biaya emisi saham.

Dalam rangka mengukur resiko, fokus perhatian kreditor jangka panjang terutama ditujukan pada prospek laba dan perkiraan arus kas. Meskipun demikian, mereka tidak dapat mengabaikan pentingnya tetap mempertahankan keseimbangan antara proporsi aktiva yang didanai oleh kreditor dan yang didanai oleh pemilik perusahaan. Keseimbangan proporsi antara aktiva yang didanai oleh kreditor dan yang didanai oleh pemilik perusahaan diukur dengan rasio debt to equity. Dimana rasio ini merupakan persentase dari hutang relatif terhadap jumlah ekuitas yang dimiliki perusahaan. Rasio debt to equity ini dapat memberikan gambaran mengenai struktur modal yang dimiliki perusahaan sehingga dapat dilihat tingkat resiko tak tertagihnya hutang. Semakin besar proporsi hutang relatif terhadap ekuitas maka semakin besar pula resiko perusahaan. Kreditor jangka panjang pada umumnya lebih menyukai angka rasio debt to equity yang kecil. Makin kecil rasio ini, berarti makin besar jumlah aktiva yang didanai oleh pemilik perusahaan, dan makin besar penyangga resiko kreditor (Prasetyo, 1995). 
Hasil analisis koefisien regresi IOS sebesar 1,733 menunjukkan hipotesis yang dikemukakan pada penelitian ini bahwa IOS berpengaruh positif terhadap price book value atau nilai perusahaan dapat terbukti. Hasil ini mendukung penelitian Rachmawati dan Triatmoko (2007) yang menunjukkan hasil adanya pengaruh positif IOS terhadap nilai perusahaan. hasil ini mengindikasikan bahwa kemampuan perusahaan dalam mengambil kesempatan investasi melalui pengeluaran atau biaya untuk mengeksploitasi kesempatan investasi masa depan dan proyek-proyek yang memberikan pertumbuhan bagi perusahaan mempengaruhi tingkat PBV perusahaan. Proksi berdasarkan investasi ini percaya pada gagasan bahwa suatu level kegiatan investasi yang tinggi berkaitan secara positif pada nilai IOS suatu perusahaan. Kegiatan investasi ini diharapkan dapat memberikan peluang investasi yang semakin besar pada perusahaan yang bersangkutan di masaberikutnya.

Penggunaan nilai pasar dalam membentuk rasio IOS menurut Hartono (2000) sudah tepat karena nilai pasar dapat mengindikasikan adanya potensi kesempatan perusahaan untuk tumbuh dan berinvestasi di masa depan. Smith dan Watts (1992) dalam Utami (2007) menunjukkan bukti bahwa perusahaan yang tumbuh memiliki nilai rasio nilai pasar terhadap nilai bukunya yang lebih tinggi dibandingkan dengan perusahaan yang tidak tumbuh. Rasio MVA/BVA dan MVE/BVE berkorelasi positif terhadap pertumbuhan aktiva dan ekuitas. Kallapur dan Trombley (1999) dalam Utami (2007) juga menemukan bukti atas korelasi tersebut secara signifikan. Fijrijanti, Tettet, dan Hartono ( 2000) menunjukan arah korelasi positif antara rasio MVE/BVE dan MVA/BVA terhadap pertumbuhan aktiva secara konsisten. Hasil penelitian Rokhiyati (2005) menyebutkan bahwa terdapat korelasi yang positif signifikan untuk perusahaan yang tumbuh terjadi antara MVEBVE terhadap pertumbuhan penjualan.

Investment opportunity set (IOS) sebagai opsi investasi masa depan yang tidak hanya ditunjukkan dengan adanya proyek - proyek perusahaan saja tetapi juga dengan kemempuan perusahaan yang lebih tinggi dalam mengeksploitasi kesempatan mengambil keuntungan. 


\section{Kesimpulan}

Hasil penelitian ini menunjukkan bahwa variabel DER dan IOS digunakan oleh investor untuk memprediksi PBV perusahaan. Investor sebaiknya memperhatikan informasi-informasi yang dikeluarkan perusahaan terutama IOS dan DER karena informasi ini berpengaruh terhadap pertumbuhan perusahaan sehingga diharapkan keputusan yang diambil tepat dalam berinvestasi di saham Bursa Efek Indonesia.

Berdasarkan analisis dan pembahasan yang telah dilakukan mengenai hubungan debt equity ratio dan investment Opportunity Set (IOS) terhadap nilai perusahaan maka kesimpulan yang dapat diambil adalah :

1. Hasil penelitian tidak terdapat konsistensi dimana nilai koefisien regresi DER sebesar 0,034 menunjukkan tanda negatif. Hasil ini mendukung penelitian yang diperoleh Setyaningsih (2000) dan Sugiarto (2007). Pernyataan ini sesuai Barclay dan Smith (1998, dalam Subekti dan Kusuma 2001) konsisten dengan prediksi teori contracting. Dan sejalan dengan pecking order theory (Myers ,2001) menyatakan bahwa "perusahaan dengan tingkat profitabilitas yang tinggi justru tingkat utangnya rendah, dikarenakan perusahaan yang profitabilitasnya tinggi memiliki sumber dana internal yang berlimpah.

2. Hasil analisis koefisien regresi IOS sebesar 1,733 menunjukkan hipotesis yang dikemukakan pada penelitian ini bahwa IOS berpengaruh positif terhadap price book value atau nilai perusahaan dapat terbukti. Hasil ini mendukung penelitian Rachmawati dan Triatmoko (2007) yang menunjukkan hasil adanya pengaruh positif IOS terhadap nilai perusahaan \& Smith dan Watts (1992) dalam Utami (2007) serta hasil penelitian Rokhiyati (2005) 


\section{Daftar Pustaka}

Sartono, Agus. 2010. Manajemen Keuangan Teori dan Aplikasi. Yogyakarta: BPFE

Noerirawan, Ronni, dkk. 2012. Pengaruh Faktor Internal dan Eksternal Perusahaan Terhadap Nilai Perusahaan. Jurnal Akuntansi Vol.1 No. 2. hal. 4.

Sudana, I Made. 2011. Manajemen Keuangan Perusahaan Teori dan Praktek. Jakarta: Erlangga.

Fakhruddin dan Hadianto, Sopian. 2001. Perangkat dan Model Analisis Investasi di Pasar Modal, Buku satu. Jakarta: Elex Media Komputindo.

Ghozali , Imam,2005, Aplikasi Analisis Multivariate dengan program SPSS, Badan Penerbit Universitas Diponegoro, Semarang 